\title{
A RECONNAISSANCE OF THE \\ BIRDS AND MAMMALS OF THE \\ CARIBOU MOUNTAINS, ALBERTA
}

\author{
E. OTTO HÖHN* and RODNEY D. BURNS**
}

\section{ABSTRACT}

Field work with collecting, in the ribou Mountains in the summer of 73 and 1974, established the sence of 84 species of birds. The st interesting of these were Redoated Loon, Northern Phalarope A Gray-cheeked Thrush. All three re seen in circumstances which ongly suggested local breeding. eeding records for the Surf Scoter d Red-breasted Merganser were obtained.

jixteen species of mammals were orded. This included heather voles, ich were trapped, and observations river otters and caribou.

The Caribou Mountains of northern perta are an isolated high plateau $h$ a number of large and small es. The center of the area lies about miles northeast of the settlement of t Vermillion. The plateau extends about 50 miles from north to south for almost 90 miles from east to t. Its altitude exceeds 3,100 feet in he places and a considerable area is or 3,000 feet high. No zoological d work has, to our knowledge, been

epartment of Physiology,

hiversity of Alberta,

monton, Alberta

G $2 \mathrm{H} 7$

latural History Division,

rovincial Museum of Alberta,

idmonton, Alberta. carried out in this area apart from some entomological work on the southern slope of the plateau and on Foggy Mountain on its southern rim, carried out in July 1970 by Drs. F. H. Gooding and B. S. Henning of the University of Alberta.

Owing to its altitude at a latitude of $59^{\circ}$, it was felt that the plateau might well harbour some birds of otherwise more northern breeding distribution. This was borne out in 1973 by the finding of Red-throated Loons, Graycheeked Thrushes and a Northern Phalarope.

Almost as striking was our failure to observe in this area a number of birds which are common in summer in northern Alberta as a whole, either in 1973 or 1974.

The absence of the House Sparrow and of Starlings is presumably related to the lack of year-round human inhabitants. Other absentees from our bird list are the Red-tailed Hawk, Marsh Hawk, American Coot, Killdeer, owls other than the Great Horned and woodpeckers other than the Common Flicker, Black-capped Chickadee, wrens and the Long-billed Marsh Wren, Red-winged Blackbird and Leiconte's and the Clay-colored sparrows. Their absence on the plateau can in most cases be explained as due to the lack of certain habitats, eg. true marshes, grasslands of any extent, and the scarcity of tall timber. 


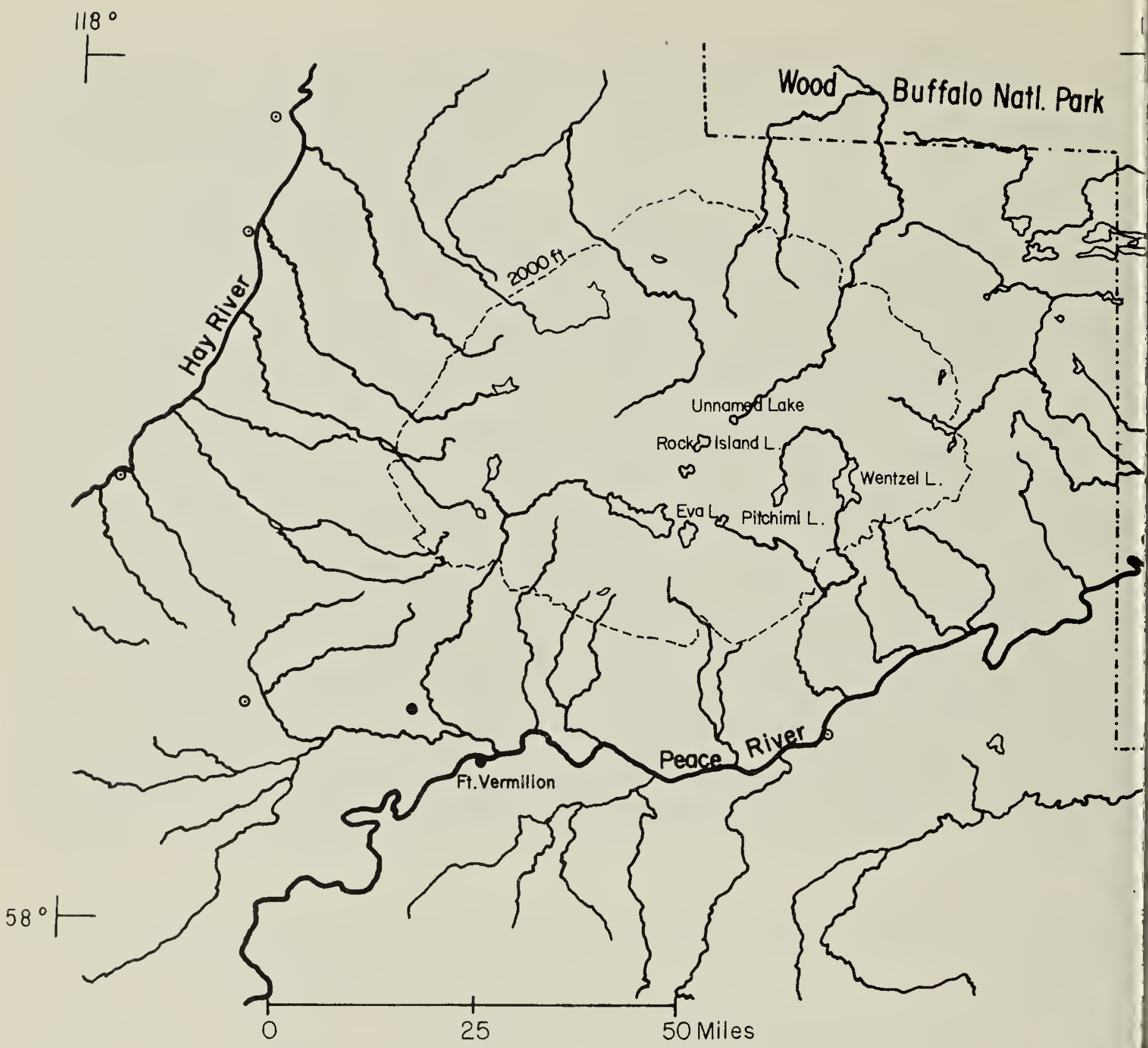

Sketch map of the Caribou Mountains showing the lakes named in the text.

\section{Itinerary}

Between us we spent 7 weeks in this area in the summers of 1973 and 1974. Our itinerary is given in some detail so that future workers who may wish to concentrate on areas we did not traverse can identify the areas we covered on large scale maps. Two of the larger lakes visited are not named on maps. They are: Rock Island Lake (so named by forestry service personnel), a lake 2 miles long from north to south and about as wide lying 6 miles northeast of the eastern end of Margaret Lake into which it drains by a creek, and Unnamed Lake about 1 $1 / 2$ miles long lying 6 miles northnortheast of Rock Island Lake and draining into the Buffalo River.

As there are no roads in the ar float-equipped aircraft of the Pe Air Company were used to reach a to return from the lakes selected camp sites.

In 1973 E. O. Höhn, accompan by P. Marklevitz, camped on Eva L and then stayed at the fish camp Margaret Lake from June 6 to 10 . 73 two more northern of the four isla $s$ in Eva Lake were visted, as well a $a$ small lake northwest of Eva Lake, northeastern portion only of the she of Margaret Lake, and a small lak 1 mile north of the fish camp.

From June 26 to 28 the same obs 
rs were camped on the western shore Rock Island Lake and visited a all lake 1 mile west of this lake and islet off its southwestern shore. hey were then flown to Margaret tke where they stayed until June 30 , siting the small lake mentioned ove and two others which lie about a le north of the eastern shore of Eva ike.

\section{In 1974 R. D. Burns, accompanied}

D. Sept, were at Unnamed Lake om June 18 to 25 and also visited a haller lake close by to the east. From ne 26 to July 7 they were camped on e east shore of Pitchimi Lake and exored two islands in this lake. From ly 8 to 15 they were camped on the st shore of Wentzel Lake.

\section{E. O. Höhn and P. Marklevitz} mped on the west shore of Rock and Lake from July 15 to 20; they isited the small lake to the west as Il as two others about 1 and 2 miles pectively $t(0)$ the southwest along the eek draining the lake.

\section{bitats}

Forests of stunted black spruce, cir lower branches hung with grey nea lichens without deciduous unrgrowth but with a floor of lichens

$\mathrm{d}$ patches of sphagnum moss, cover most extensive areas. Reindeer ss (Cladonia rangifera) was the most despread lichen but Cladonia mitis d Cladonia coccifera as well as traria nivalis were also collected. tches of more luxuriant forest with admixture of birch, white spruce d lodgepole pine were noticed on ands in Eva Lake and on the shores Pitchimi and Wentzel Lakes. Forer burns had produced more open eas with only scattered young spruce a bed of lichens or in some places extensive growth of labrador tea. illow and alder thickets were found nng lakes and creeks. Meadows were lall and scarce but were seen on cleared ground about the Margaret Lake fish camp; some of the seismic trails were grass-grown and some islands in lakes had grassy areas. Emergent water plants in shallow portions of some lakes produced an approximation to marsh vegetation. Segments of the shores of some of the larger lakes have narrow sandy beaches and shore-line areas of alders growing out of a mat of bearberies.

\section{SYSTEMATIC LIST}

In the list which follows, an asterisk preceding the species name indicates that one or more specimens were collected locally. All bird specimens obtained are in the Provincial Museum of Alberta at Edmonton, as are those of mammals taken by R.D.B.: E.O.H.'s mammal specimens are in the collection of the Department of Zoology of the University of Alberta. Except in the case of the White-crowned Sparrow, the subspecific identity of the specimens has not been established and trinomials have therefore been used only in that instance. The names of species not observed by either author but included on the basis of local information, mostly obtained from Mr. George Grimm of Manning, Alberta, who has owned the sport fishing camp at Margaret Lake for a number of years, are placed in parentheses. Species names are from the A.O.V. Checklist and supplement. "'

The names of the larger lakes about which most observations were made are indicated by the following abbreviations; Eva - E: Margaret - M: Pitchimi - P; Rock Island - R; Unnamed - U: Wentzel - W. The phrase "all large lakes visited" refers to these lakes as a whole. The altitudes in feet of these lakes, in ascending order, are: Wentzel - 2.150 approx.; Pitchimi and Unnamed $-2,500$ approx.: Margaret - 2,725; Eva 2,887: Rock Island $-2,950$ approx. 
COMMON LOON. Seen on all the large lakes visited, as many as nine being in sight together on one occasion: single birds seen also on some of the smaller lakes. One flushed from a nest with two eggs on the narrow terminal spit of an island in $E$ lake June $8 / 73$.

RED-THROATED LOON. Not previously recorded in Alberta during the breeding season (Salt and Wilk, 1966), though there is a breeding record for northern Saskatchewan (Nero, 1963). A few pairs evidently summer in the Caribou Mountains near $R$ lake but proof of nesting has not yet been obtained. Two seen on a small lake near $M$ lake and one encountered on a nearby trail June $9 / 73$ but none here on June 26 . One, at times two, R lake June 26-28/73 (Höhn and Marklevitz, 1974). In 1974 some seen daily on $\mathrm{R}$ lake July 16-19; on the evening of July 17 five in a display flight accompanied by $k a k a k a k w a o$ calls while another was swimming. Individuals were seen to leave $\mathrm{R}$ lake with a fish in the beak on two occasions: these and others too far to determine whether they carried prey, generally left the lake in the same southwesterly direction but no loons were seen on two smaller lakes in this direction which we visited.

RED-NECKED GREBE. One on a small lake northwest of $E$ lake June $8 / 73$ anc least one, probably two, pairs on anot small lake northeast of $M$ lake June 29 HORNED GREBE. Two near a nest o small lake west of $\mathrm{R}$ lake June 28/73 two on another small lake nearby on same day. On July 16/74 two on the fi mentioned lake.

WHITE PELICAN. One on W lake $9 / 74$.

MALLARD. A generally distribu breeding bird but not seen on $W$ lake; sc cer than in lower-lying country; exclud downies maximum seen in one day Females with downies seen near $\mathrm{R}$ and lakes in late June 1973.

GADWALL. A pair seen on $M$ lake June $8 / 73$.

PINTAIL. A fully-feathered young bird 1 a lakelet near $\mathrm{R}$ lake on July $16 / 74$.

GREEN-WINGED TEAL. Theres probably a moderate, scattered breer g population. A few were seen on $E$ lak 1 June 1973 and others near $R$ lake in e June of the same year as well as one o a small lake nearby. In June 1974 two sir e birds at P lake and a flock of 10 at $\mathrm{R} \mathrm{l}$ e in mid-July.

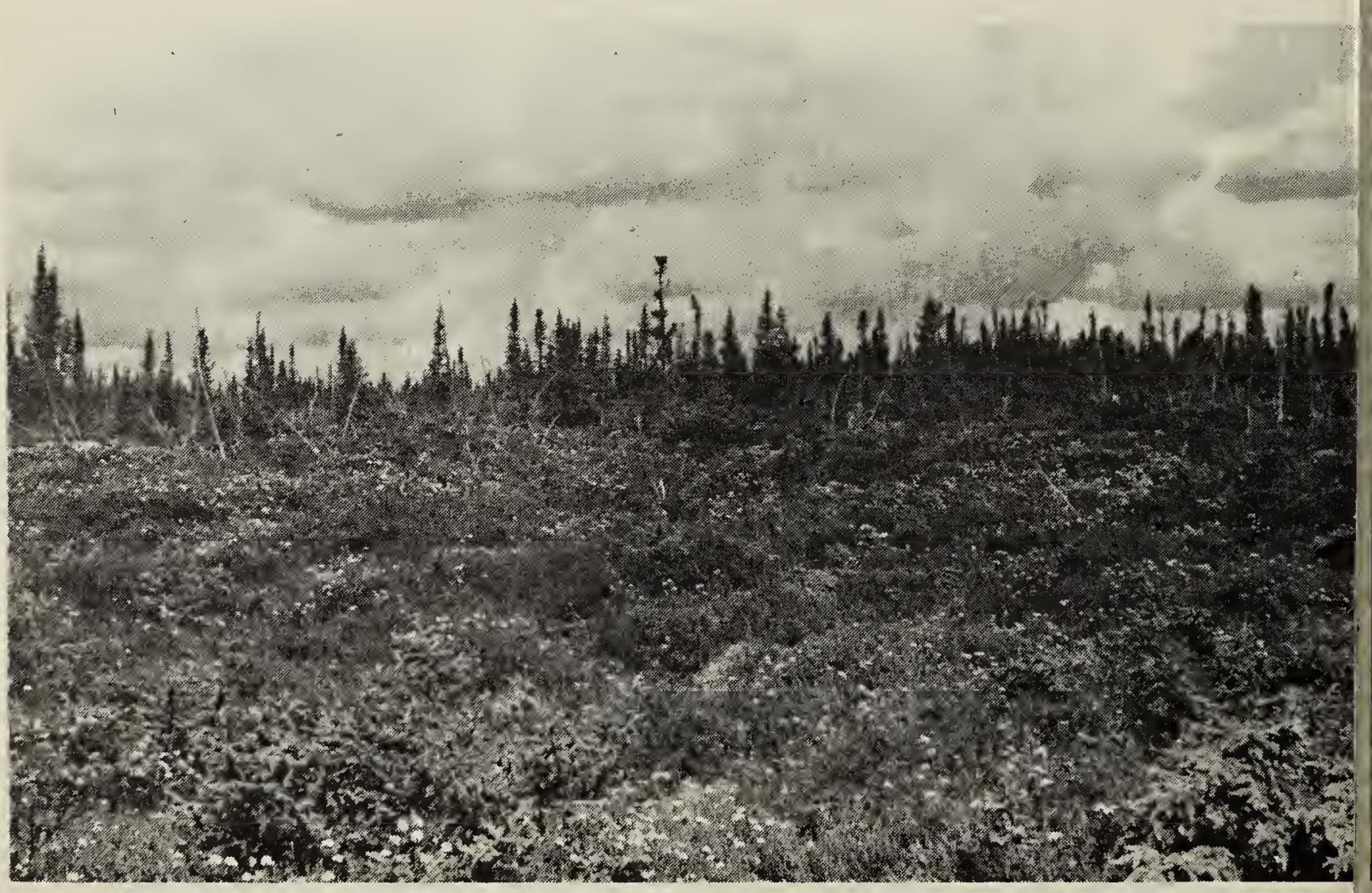

An old burn near Rock Island Lake, typical habitat of the Gray-cheeked Thrush. 
MERICAN WIGEON. A thinly stributed breeding bird. A few on E lake early June 1973. Next year two females en at U lake and a female flushed from a st with nine eggs on June 18: on July 2 a male with a single young seen at $P$ lake.

iREATER SCAUP. A number of these en on several waters in June 1973 and ly 1974 seemed to E.O.H. and his comnion to show the wing pattern of this ecies when in flight. As no specimens ere collected, their identity was not tablished. The map of the breeding range ven in Godfrey: shows it as extending Ell south of Great Slave Lake - breeding this species in the Caribou Mountains is t improbable.]

ESSER SCAUP. Seen at all larger lakes ited except $W$ lake and also seen on me smaller lakes. On a lake about a mile hg, lying northeast of the east shore of $\mathrm{M}$ ke, there were over a hundred of these cks, males greatly in excess, on June 173 .

PMMON GOLDENEYE. Scarce, ssibly because of the rarity of trees large ough to carry nesting holes. A pair was $M$ lake on June 7 and a female only on ne $29 / 73$. A lone female on $\mathrm{R}$ lake on ne $29 / 73$ and a male on P lake on July 74.

JFFLEHEAD. This tree-nesting duck is idently also scarce but proof of breeding is obtained. Seen in small numbers on all ger lakes visited except E lake; greatest mber observed was a group of about enty, mainly males, on a small lake rtheast of the eastern end of $M$ lake on ne 20/73. A female with five downies on pool near P lake on July $5 / 74$.

LDSQUAW. On June 30/73 a male and a male flew past E.O.H. and his comnion, about 35 yards away, along the ore of a small lake a mile due east of the lake fish camp. The male was in full eeding plumage and gave the characristic spring call. These were presumably n-breeders which had not completed eir spring migration. ${ }^{4}$

HITE-WINGED SCOTER. Recorded ly in the $M$ lake area; a male on a small arby lake June 9 and a group of seven of th sexes on another small lake on June $/ 73$.

URF SCOTER. As Salt and Wilk's state at there is no Alberta nesting record, ough it probably breeds in the Lake habasca region on the basis of June and ly occurrences, the breeding record low is of interest. Common on all larger $\mathrm{k}$ 's visited as well as on some of the smaller lakes. A female with four young on a muskeg pool near W lake on July $9 / 74$.

COMMON MERGANSER. Well distributed in small numbers, may breed. Seen on P, W, and R lakes: as many as seven males and a female in a group on the first-named lake on June 28/74. A male followed by a file of downy young on $\mathrm{W}$ lake on July 10/74; as males normally desert the females during incubation these downies were not necessarily those of the male seen with them or even of his species.

*RED-BREASTED MERGANSER. Fairly well distributed in small numbers: breeds locally, a point of interest as Salt and Wilk' state there are no unequivocal breeding records for Alberta. Seen on E, M, and $P$ lakes. At $P$ lake a female flushed off a nest with eight eggs beneath a fallen log on a small island on July $2 / 74$.

GOSHAWK. A nest with three wellfeathered young found 25 feet high in a white poplar in a stand of mature trees of this species at $W$ lake on July 8/74: no adults were seen near the nest but single adults referred to it were seen in the area two and three days later.

BALD EAGLE. Seen on all larger lakes visited and probably breeds on all of them. A nest which had evidently been used that year, for egg shells were found beneath it, was seen on an island in E lake on June $8 / 73$. An unoccupied nest was found on an island in P lake on July $2 / 74$

OSPREY. There are probably several breeding pairs in the area. Two were seen at M lake on June 10/73 and fishermen told us that a pair had nested a few years earlier at $\mathrm{W}$ lake. At $\mathrm{R}$ lake one was seen daily and sometimes twice daily from July 16-19/74 fishing in the lake. It repeatedly left with a fish in its talons, disappearing between the shore-line trees and no doubt had young in the nest not too far off. One was seen by a smaller lake about 2 miles from $\mathrm{R}$ lake on July 18 of the same year.

AMERICAN KESTREL. Single birds seen at $M, U, P$, and $W$ lakes: on one occasion two were in sight at the latter locality.

SPRUCE GROUSE. Breeds but distribution very local in the two years of our observations. G. Grimm told E.O.H. there were always a few about. None were seen about E, M, and R lakes. At P lake a hen with six young on July $6 / 74$ and another female with young at $\mathrm{W}$ lake in July of the same year.

I WILLOW PTARMIGAN. G. Grimm told E.O.H. that ptarmigan sometimes appeared in numbers about the $M$ lake fish camp at 
the time of the first severe cold of the winter, probably in November. I

COMMON SNIPE. Apparently local. One heard drumming at $R$ lake in late June 1973: next day one seen near a smaller lake in that area.

SPOTTED SANDPIPER. There are evidently several breeding pairs on all of the larger lakes. Nests each with four eggs were found at $M$ and $R$ lakes in June 1973 and at $\mathrm{P}$ and $\mathrm{W}$ lakes in June and early July 1974.

SOLITARY SANDPIPER. Scarce. One near $M$ lake on June $9 / 73$ showed mild anxiety at our presence and another near $\mathrm{R}$ lake on July 18/74 showed definite anxiety and probably had young nearby.

GREATER YELLOWLEGS. Probably breeds in small numbers. Two attributed to this species between $E$ and $M$ lakes on June $8 / 73$ and two others near $R$ lake on July $18 / 74$.

LESSER YELLOWLEGS. Widely distributed, breeds. Seen at all larger lakes visited except $W$ lake, as well as on a number of the smaller lakes. On June 29/73 at a small lake near $M$ lake there were two very anxious adults and two downy young.

BAIRD'S SANDPIPER. One present for most of the day on a sandy strip of shore at R lake on July $17 / 74$.

${ }^{*}$ LEAST SANDPIPER. Four at $\mathrm{P}$ lake on July 4/74: at W lake on July 14 of the same year a mixed flock of these and Semipalmated Sandpipers. One at $R$ lake on July $18 / 74$. There were no brood patches on two collected at $W$ lake and these were presumably fall migrants from some fairly distant area.

* SEMIPALMATED SANDPIPER. Two at W lake on July $10 / 74$ and a somewhat greater number together with Least Sandpipers on July 14.

NORTHERN PHALAROPE. One seen June $28 / 73$ on a small lake west of the west shore of $\mathrm{R}$ lake showed intense anxiety at our presence and probably had young nearby (Höhn and Marklevitz, 1974). No phalaropes were seen at this lake when it was revisited in July 1974. The only geographically comparable record is that of Nero" for northern Saskatchewan.

${ }^{*}$ HERRING GULL. Some seen at all the larger lakes visited. There is a breeding colony on an islet in $\mathrm{R}$ lake where about ten pairs of adults and at least four young were seen on June $28 / 73$. There may well be other small nesting colonies in the area.

CALIFORNIA GULL. One at U lake on
June 21: seven over P lake on July 4 , a one at $W$ lake on July $8 / 74$.

RING-BILLED GULL. One at $M$ lake June 10/73. It seems improbable that $t$ or the preceding species nest in the area

MEW GULL. One seen repeatedly at $\mathrm{t}$ fish camp on $M$ lake on June 8,10 a 28/73: several at $E$ lake in early June that year. At $\mathrm{R}$ lake two were seen on $\mathrm{J}$ $18 / 74$. May well breed in the area since occurs in the breeding season at other lak in northern Alberta though the near known nesting colony is at Fort Smith.

BONAPARTE'S GULL. Wide distributed, evidently breeds. Some seen all larger lakes visited as well as on a nut ber of smaller ones. At several of the latt birds in couples or in small groups show by their anxiety that they had you nearby.

*COMMON TERN. Apparently bree near or on the two largest lakes of the ar seen on $E, M$, and $W$ lakes. At a small la northeast of $M$ lake several terns were se carrying fish to a grassy islet on June $30 / 7$ Up to two dozen terns were seen in the at times over an apparent colony on island in W lake in mid-July 1974.

BLACK TERN. Our only record is of th seen over a small lake near $\mathrm{R}$ lake on Ju 28/73: none were seen there on a seco visit in mid-July 1974.

GREAT HORNED OWL. No owls we seen in the area but a wing feather of an $O$ of this species was found near $M$ lake June 1973 and another near R lake in J 1974.

COMMON NIGHTHAWK. Widespre: presumably breeds. One to several bir were seen virtually in all areas visited 1973 and 1974.

COMMON FLICKER. This was the of woodpecker observed. Single birds seen $M, P, R$, and $W$ lakes. Breeding seem likely on an island in $P$ lake where t" were seen on July $2 / 74$ in an area whe several possible nesting cavities in tre were available.

YELLOW-BELLIED FLYCATCHER. good view of one was obtained on the $e$ shore of $M$ lake on June $8 / 73$.

ALDER FLYCATCHER. The call of $t$ flycatcher was heard in a willow-alc habitat on the east shore of $M$ lake on Ju 8 and in a similar area at $R$ lake on $J \iota$ 27/73.

LEAST FLYCATCHER. One was seen 3 heard at $E$ lake on June $8 / 73$ and anothel P lake on July $4 / 74$. 


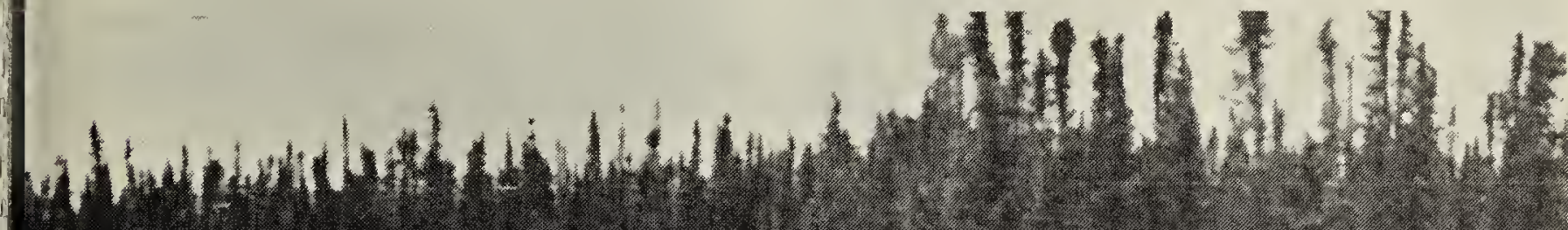

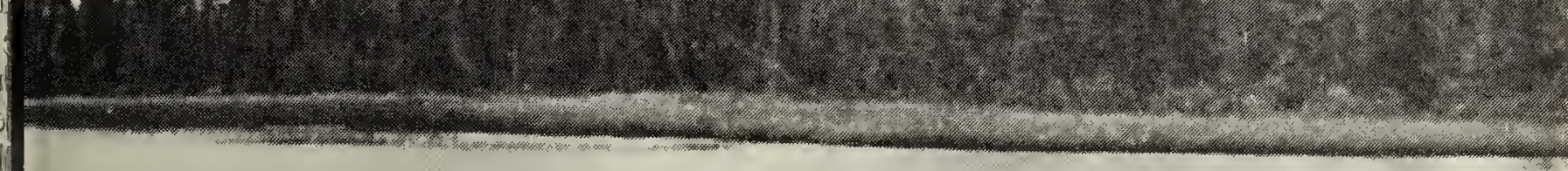

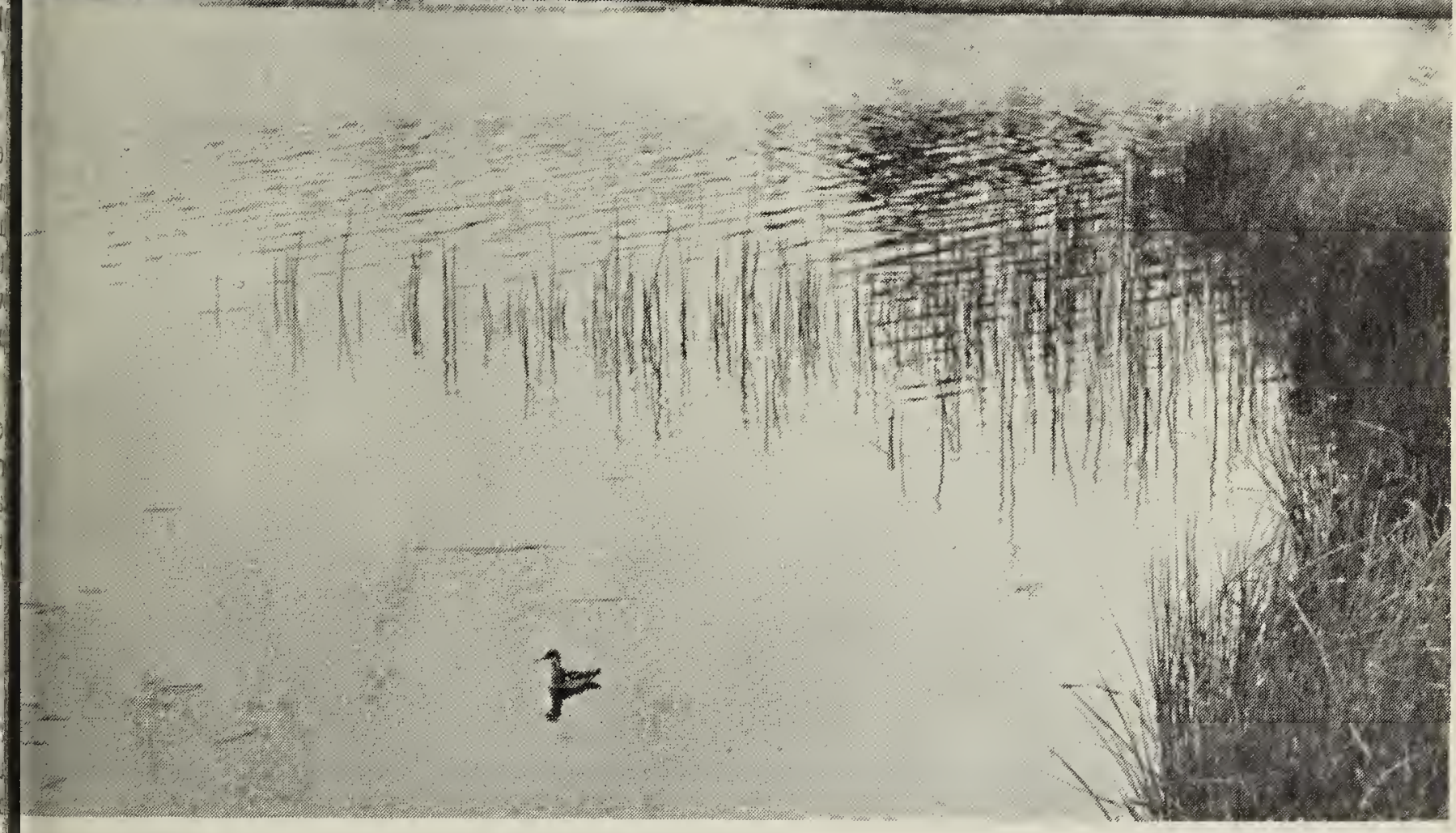

prthern Phalarope on the small lake near Rock Island Lake,

E. O. Höhn

DLIVE-SIDED FLYCATCHER. This catcher was scarcer than might have en expected. Single birds were seen at U, and W lakes in June and July 1974.

REE SWALLOW. A thinly distributed eeding bird. Seen in very small numbers $M, U$ and P lakes; two tentatively idenied at $\mathrm{R}$ lake. At $\mathrm{P}$ lake one was flushed $\mathrm{pm}$ a nest hole in a dead birch on an and on July $2 / 74$.

BANK SWALLOW. Only observed near lake where a bank on the shore of a arby lesser lake held six occupied nests; o out of three nests examined held eggs June $21 / 74$.

ARN SWALLOW. Probably only an ocsional visitor from surrounding areas; he near M lake fish camp on June 28/73.

SRAY JAY. A well distributed breeding rd. Small groups often including young of e year seen in all areas visited.

OMMON RAVEN. Single birds or uples seen in all areas visited; the sighting of two adults with a young of the year at $P$ lake on July $1 / 74$ indicates local breeding.

* BOREAL CHICKADEE. Scarce but apparently breeds. Seen only at M, P, and R lakes. A family group with young of the season was seen at $P$ lake on July $2 / 74$.

AMERICAN ROBIN. Well distributed and breeds but in small numbers; one or two seen in all areas visited and a nest with three eggs found at $P$ lake on July $3 / 74$.

HERMIT THRUSH. Apparently restricted to relatively low-lying portions of the area where it breeds. Nests with eggs were found at $U$ and $W$ lakes in late June and early July 1974; it was also seen at P and M lakes.

SW AINSON'S THRUSH. Only observed at $P$ and $W$ lakes but fairly numerous about the former. Probably restricted to the lower-lying portions of the area.

${ }^{*}$ GRAY-CHEEKED THRUSH. During our stay at $\mathrm{R}$ lake, June 26-28/73, there were about twenty along half a mile of the 
west shore of the lake; several seen with food in the beak suggesting young were nearby.' During July 16-29/74 only one seen in this area; presumably most had already left this apparent breeding area by then. One heard singing at $U$ lake June 22 and 23/74 and one collected there June 25.

RUBY-CROWNED KINGLET. Some observed in all areas visited.

*BOHEMIAN WAXWING. May breed in the area. A male was collected at $U$ lake on June 21/74; several sightings made later at $P$ lake. the largest a flock of twenty-three on June 29: a small flock at W lake July 11 14 of the same year. Elsewhere only a waxwing call heard in early June 1973 near M lake.

[NORTHERN SHRIKE. On June 6/73 two of us had a very brief view of a gray shrike presumed to be of this species.]

RED-EYED VIREO. A singing male seen on an island in E lake on June $8 / 73$.

*TENNESSEE WARBLER. Local, presumably breeds; common and evidently established in territories in areas where there were young deciduous trees or in willow-alder thickets about $P$ lake in June 1974 and in a willow-alder area on M lake in June 1973.

ORANGE-CROWNED WARBLER. One seen at $M$ lake on June $8 / 73$, and several on an island in E lake on the following day.

YELLOW WARBLER. Evidently less common than in more low-lying country; breeds. One to several, including a pair, were seen at $U$ and $P$ lakes in June 1974. At $\mathrm{R}$ lake a male was seen on a shore-line tree with a fully-fledged young bird judged to be of the same species on July 19/74.

MAGNOLIA WARBLER. Our only observation is of several seen on an island in $E$ lake on June $8 / 73$.

YELLOW-RUMPED WARBLER. A common and generally distributed breeding bird. Seen in some numbers in all areas visited in a variety of treed and partly-treed habitats. Family parties with young of the year about R lake in July 1974.

BLACK-THROATED GREEN WAR BLER. A singing male observed for some time near the shore of $E$ lake on June $8 / 73$ is our only observation of this species.

*BLACKPOLL WARBLER. A widely distributed breeding bird; fairly common in all areas visited both in fairly open, formerly burnt areas as well as in habitats with more trees. Several young out of the nest seen with adults at $R$ lake in mid-July 1974.
*PALM WARBLER. A widely distribu breeding bird. This warbler was fairly co mon in all areas visited, generally in fai open burns but also found in mixed wo habitats. At $\mathrm{P}$ lake on July $5 / 74$ two ma and a female were seen gathering inse evidently for their young but no nest co be found.

NORTHERN WATERTHRUSH. Our s observation is of one well seen on an isla in E lake on June 8/73.

COMMON YELLOWTHROAT. App ently local but may breed. Single birds sc or heard singing in a willow-alder area the east shore of $M$ lake on June 6 a $8 / 73$.

*WILSON'S WARBLER. Apparen breeds generally in willow or willow-al scrub areas, seen in such habitats as $P$, $\mathrm{M}$, and $\mathrm{R}$ lakes. One seen at $\mathrm{M}$ lake wit beakful of food on June $30 / 73$, eviden had young nearby.

AMERICAN REDSTART. Observed o on an island in $E$ lake where there w several on June $8 / 73$.

*RUSTY BLACKBIRD. Fairly comm breeds. Some were observed near large a small lakes and along creeks in all ar visited except $W$ lake. At $U$ lake a fem seen feeding a young bird out of the nest June $25 / 74$; by July 7 flocks of up to were seen at $\mathrm{P}$ lake and their apparent sence at $W$ lake which was not visited $u$ July 8 might have been due to their pr departure from that area.

PINE GROSBEAK. Only one observat - a female seen between $E$ and $M$ lakes June $6 / 73$.

COMMON REDPOLL. Two seen fo short period at $U$ lake on June 25/74.

PINE SISKIN. Three seen at $W$ lake July 14 and one near $R$ lake on July 17

WHITE-WINGED CROSSBILL. Only observation but it suggests local breed A juvenile heavily streaked below was $s$ at $R$ lake on July $27 / 73$ and later on 3 same day a group of four which inclur 1 two males in full plumage was encounte 1 there.

* SAVANNAH SPARROW. Fairly comn in the limited grassy areas and also on sc burns about all the larger lakes visited cept W lake. A nest of five eggs found a 1 lake on June 10/73.

${ }^{*}$ DARK-EYED JUNCO. Fairly commor all areas visited, evidently breeds as fan parties with young of the year seen in ei July. 
lynx as numerous, and that his staff had seen signs of porcupines and wolverines.

* MASKED SHREW. An adult male trap. ped in an old cabin at P lake July 2/74.

* AMERICAN WATER SHREW. An adult male trapped on the rocky shore of $P$ lake July $1 / 74$.

SNOWSHOE HARE. The skulls of about half a dozen were found on a trail near $M$ lake on June $9 / 73$ and on June 29 of that year a hare seen on the same trail. The species was presumably at a low during the period of our observations.

* LEAST CHIPMUNK. Local, perhaps confined to relatively low-lying areas where the vegetation is more rich and varied for it was only seen at $M$ and $W$ lakes where an immature male was collected on July $11 / 74$.

*AMERICAN RED SQUIRREL. Fairly common in all areas visited. An adult female in post-lactating condition collected at $P$ lake June $26 / 74$ as well as an immature at W lake in July of that year.

AMERICAN BEAVER. Fairly common for some seen in small numbers at $\mathrm{U}, \mathrm{P}, \mathrm{W}$, and $\mathrm{M}$ lakes as well as on several smaller lakes and several lodges seen.

* DEER MOUSE. Possibly restricted to lower-lying portions of the plateau with relatively rich vegetation, for specimens trapped only near the fish camp at $M$ lake and at W lake.

*GAPPER'S RED-BACKED VOLE. Evidently the most common murid in the area for several were caught wherever traps were set, i.e. at E, M, R (in 1973 and 1974) and W, P, and W lakes (in 1974). Adults in breeding condition, including pregnant females, post-breeding adults as well as immatures were taken.

${ }^{*}$ HEATHER VOLE. An adult male trapped in June 1973 at $R$ lake and another in much the same locality in July 1974.

MUSKRAT. Only observed about the mouth of a creek at the east end of $M$ lake in June 1973 where there were several but G. Grimm says this species and beaver were common in all the lakes of the area.

* MEADOW VOLE. Apparently confined to grassy areas and as these are few and far between, probably very local. We trapped one at $M$ lake and were able to capture a large adult on the grassy shore of a smaller lake northeast of M lake in June 1973.

WOLF. G. Grimm told E.O.H. it was fairly common; this seems to be confirmed by our findings of tracks in mud on seismic trail near R lake in June 1973 and July 1974: a there are no dogs in the entire area th identity of large canine footprints is beyon doubt. Droppings attributed to this specie were also found at W lake in July 1974.

[RED FOX. Evidently scarce: G. Grimı told E.O.H. he had only seen one, in 1971 ive saw none nor any indications of the presence.|

AMERICAN BLACK BEAR. Bears are at parently much scarcer on the Caribo Mountain plateau than in the surroundin lower country. G. Grimm had only know of one about $M$ lake in all his years in th area. A yearling was seen several times at lake between June 26 and 30/74: it w feeding on remains left by fishermen. At lake fresh bear signs were found in Ju 1974 and about the same time droppin attributed to this species were found at lake.

RIVER OTTER. G. Grimm told E.O.H. had once seen two otters on $M$ lake. June 23 two were seen swimming across lake and then ascending a creek whi flows into it.

CARIBOU. The very name of the area dicates that it once held a good populati of woodland caribou. The many tra evidently made by these animals, whi follow the shores of all the lakes visited, well as certain creeks, suggest that this $u$ the case until comparatively recently. pilot of Peace Air Service told E.O.H. th during the five years (preceding 1973) had known the area, caribou had decreas very noticeably. On the other hand Grimm in 1973 rated them as fairly co mon. One of our parties found fresh trac as well as the antlers of four animals. June $9 / 73$ fishermen reported seeing a d with calf on the shore of $M$ lake to other party which on the 10th saw a $\mathrm{c}$ with calf on the shore of a small lake tween $M$ and $E$ lakes from the air. Early the morning of July $18 / 74$ a doe with o was seen on the south shore of $R$ lake. $T$ animals followed the lake shore westw: crossing the creek which flows out of lake and in the course of about an ho reached our camp on the west shore of lake which they by-passed, after be startled by our presence, on the land-w side.

|MULE DEER. According to G. Gril mule deer are occasionally seen in Caribou Mountains.|

MOOSE. Rated as scarcer than caribou G. Grimm. Fishermen reported a male : lake on July 6/74: fishermen on this 1 : reported seeing a cow and calf on 
Hlowing day; moose sign was fairly comon around this lake and moose dung was so found west of R lake in July 1974.

MERICAN ORNITHOLOGISTS' UNION. 1957. Check-list of North American Birds. 5th Edition. Baltimore: Port City Press. 691p.

1973. Thirty-second supplement to the American Ornithologists' Union check-tist of North American birds. Auk 90:411-419.

SODFREY, W. E. 1966. The hirds of Canada. National Museum of Canada, Bulletin 203. $428 \mathrm{p}$.

\section{AN INTERESTING MERLIN}

by DAVID L. SURKAN*

On 8 February, 1975 while walking me from classes at the University of skatchewan, I noticed a bird trying take off from a snowbank in front of e University Hospital. After a short ase, I picked up the bird and ideniied it as a Merlin. Dr. Stuart ouston and I determined that the tip its beak was damaged and it was eeding - in addition, it was wearing band. It was a Merlin banded as a stling by Stuart Houston on 25 June, 74 at a nest described by Lynn iphant. ${ }^{2}$

Merlins have wintered in Saskatoon $r$ at least 20 years, perhaps in sponse to the large number of small rds which now winter in Saskatewan cities. The A.O.U. Check-list $1957^{1}$ indicates Wyoming, Colorado d occasionally Nebraska and Iowa the northern most wintering states this species. We are not sure ether local Merlins or birds perhaps m further north, winter here. We e not sure which subspecies winters re. The light coloured subspecies, lco columbarius richardsonii, had virally disappeared as a nesting species $\mathrm{m}$ the prairies of Saskatchewan by 1960's. We strongly suspect, but ve no conclusive proof, that it is

2524 th St. West,

ince Albert, Saskatchewan. jV 4 N4.
${ }^{4} \mathrm{HOOHN}$, E. O. and MARKLEVITZ, P. 1974 Noteworthy surnmer ohservations of hirds in the Carihou Mountains, Atherta. Can. FieldNaturalist 88:77-78.

"NERO, R. W. 1963. Birds of the Lake Athahasca region, Saskatchewan. Saskatchewan Natural History Society, Special Publication No. 5 , $143 \mathrm{p}$.

"SALT, W. R. and WILK, A. L. 1966. The hirds of Atherta. Queen's Printer. Edmonton. $511 \mathrm{p}$.

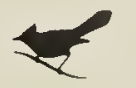

pale prairie subspecies that is making a "comeback" in the Saskatoon area.

An adult pair of Merlins was seen early in March, 1975, by Tom Donald re-establishing territory at one of the 1973 nesting sites. We conclude that both adults and their young remain in Saskatchewan the year round. Study of the injured Merlin revealed a very pale plumage of an immature male which is typical of the richardsonii subspecies.

The Merlin had a fractured left ulna as shown in $\mathrm{x}$-rays taken by David Pitt Brooke and Lynn Oliphant, Western College of Veterinary Medicine. The wing was bandaged, and Bob Rafuse undertook to care for the bird until the wing healed. The Merlin will probably be released in June.

I wish to thank Dr. Houston for his assistance in preparing this note.

\footnotetext{
'AMERICAN ORNITHOLOGIST'S UNION, 1957. Check-list of North American hird's. 5th Edition. Port City Press, Baltimore. 691 p.

"OLIPHANT, LYNN W. 1974. Merlins - the Saskatoon Falcons. Blue Jay 32: 140-147.
}

\section{REQUEST FOR MERLIN SIGHTINGS}

Any information on Saskatchewan merlin (pigeon hawk) nestings or even sightings during the breeding season would be greatly appreciated to supplement a general survey of these birds in the province.

L. W. Oliphant Department of Veterinary Anatomy University of Saskatchewan SASKATOON, Saskatchewan Telephone: $343-5785$ $242-4530$ 